\title{
KOMPETENSI PETANI JAGUNG LAHAN GAMBUT DI DESA LIMBUNG, KABUPATEN PONTIANAK, KALIMANTAN BARAT
}

\author{
Malta \\ Universitas Terbuka \\ malta@ut.ac.id
}

\begin{abstract}
Agricultural development is a series of efforts to increase farmers' income, to create employment, to alleviate poverty, to assure food security, and to encourage regional economic development. By increasing agricultural products, it is hoped that farmers will be able to improve their income. In line with this effort, the quality of human resources in the field of agriculture is one of the essential factors in increasing agricultural products.

The aims of this study were (1) to learn the competency level of corn farmers in peatlands, and (2) to identify the farmers characteristics related to the competency of corn farmers in peatlands. The research method used was descriptive-corelational. The research population consisted of 38 corn farmers in peatlands at Limbung village in Pontianak district, while the data collection was conducted on census basis from the 38 farmers. The data collection was carried out from August until September 2007. The analysis of the data was performed by using the correlation test of Rank Spearman.

The research results showed that (1) the competency of corn farmers was of average level, (2) the competency. was closely related to the age, formal education, and experience.
\end{abstract}

Key words: corn farmer, competency, peatlands

\section{PENDAHULUAN}

Pembangunan pertanian merupakan rangkaian upaya untuk meningkatkan pendapatan petani, menciptakan lapangan kerja, mengentaskan kemiskinan, memantapkan ketahanan pangan, dan mendorong pertumbuhan ekonomi wilayah (Deptan, 2005a). Melalui peningkatan produksi hasil pertanian dapat diupayakan peningkatan pendapatan petani (Soekartawi, 1995).

Salah satu upaya untuk memacu produksi hasil pertanian adalah dengan program ekstensifikasi lahan gambut (Nursyamsi et al., 2000). Lahan gambut merupakan sumberdaya alam yang melengkapi keanekaragaman kekayaan alam Indonesia. Potensi lahan gambut Indonesia mempunyai luasan sekitar 20 juta hektar (Kristijono, 2003). Kalimantan Barat merupakan propinsi yang memiliki lahan gambut terluas di Indonesia. Luas lahan gambut di Kalimantan Barat mencapai 1.993.519 hektar dan diperkirakan sekitar 15 persennya (299.028 ha) dapat dimanfaatkan untuk lahan pertanian (Harniati, 2000).

Salah satu tanaman yang banyak dikembangkan di lahan gambut adalah tanaman jagung (Zea mays $L$ ). Jagung adalah salah satu komoditas pertanian yang dapat diusahakan dengan baik di lahan gambut. Jagung merupakan komoditas pangan utama nasional, di samping beras dan kedelai; sehingga memiliki nilai ekonomis yang strategis. Jagung digunakan sebagai makanan pokok kedua setelah beras dan dapat juga diproses lebih lanjut sebagai 
pakan ternak atau bahan baku industri sehingga mempunyai prospek pemasaran yang sangat baik (Harniati, 2000).

Peluang pasar hasil panen tanaman jagung di tingkat nasional maupun di Kalimantan Barat cukup besar. Kebutuhan jagung nasional mencapai 13,8 juta ton per tahun, sedangkan produksi jagung dalam negeri 13,2 juta ton; sehingga sekitar 600 ribu ton jagung diimpor dari negara lain (Prabowo, 2007). Kebutuhan jagung untuk Kalimantan Barat mencapai \pm 52.232 ton per tahun, sedangkan persediaan jagung yang dapat dihasilkan oleh produksi dalam daerah Kalimantan Barat hanya 38.246 ton; berarti masih kekurangan sebesar 13.986 ton setiap tahunnya yang didatangkan dari luar Kalimantan (Deptan, 2005b). Data ini menunjukkan bahwa peluang pasar jagung sangat cerah.

Lahan gambut sudah sejak lama dijadikan sebagai lahan usaha tani, terutama untuk komoditas jagung dan padi, namun teknologi yang diterapkan oleh petani masih bersifat tradisional, sehingga hasilnya relatif masih rendah yaitu sekitar 1 sampai 1,6 ton jagung per hektar (Pasandaran dan Faisal, 2003); padahal penelitian Suastika dan Inu, melalui usaha tani jagung di lahan gambut dapat menghasilkan jagung 4,5 ton/ha (Harniati, 2000).

Pengelolaan lahan gambut untuk usaha tani jagung membutuhkan keseriusan dan harus menggunakan teknologi yang tepat, hal ini berkaitan dengan keahlian dalam pengolahan lahan dan teknis budidaya (penanaman, pemupukan, pemeliharaan, pengendalian hama dan penyakit, panen, dan pascapanen), disamping kompetensi petani dalam merencanakan kegiatan usaha tani dan memasarkan hasil.

Sejauhmana tingkat kompetensi petani jagung dalam berusaha tani di lahan gambut dan karakteristik petani yang berhubungan dengan kompetensi tersebut sangat penting dikaji, yang selanjutnya dapat dijadikan sebagai dasar dalam pengembangan kompetensi petani. Berdasarkan hal tersebut, maka penelitian ini bertujuan untuk menjelaskan: (1) bagaimana karakteristik petani jagung di lahan gambut; (2) sejauhmana tingkat kompetensi petani jagung di lahan gambut; dan (3) bagaimana hubungan karakteristik dengan kompetensi petani jagung di lahan gambut. Kerangka berpikir untuk menjelaskan tujuan penelitian terangkum dalam gambar berikut:
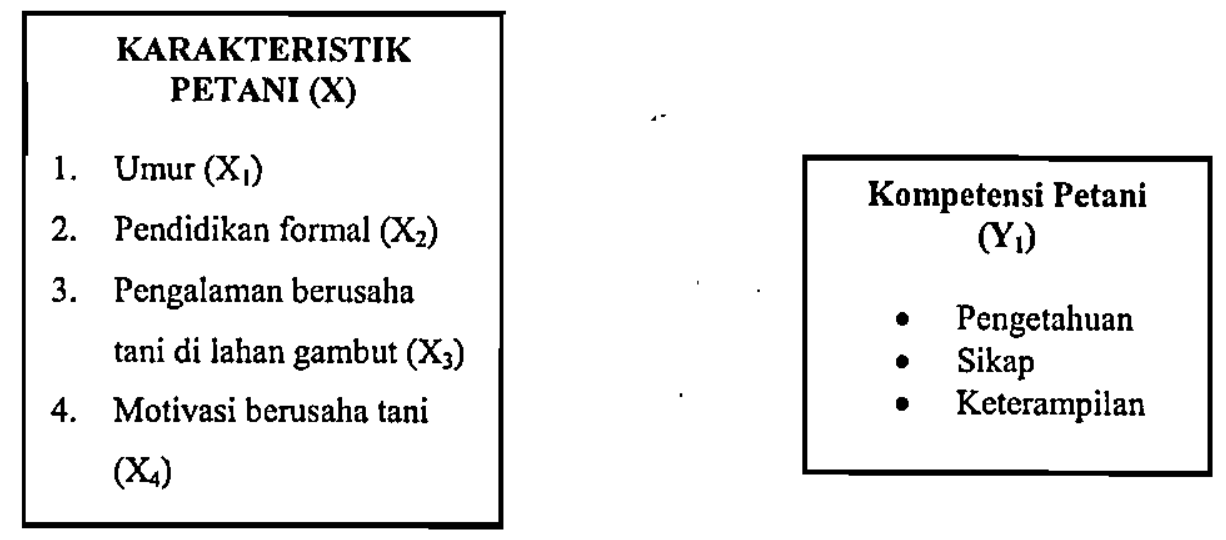

Gambar Kompetensi Petani Jagung di Lahan Gambut

Penelitian dilakukan pada bulan Agustus sampaj September 2007 di Desa Limbung Kabupaten Pontianak Provinsi Kalimantan Barat. Populasi penelitian adalah semua petani jagung di lahan gambut di Desa Limbung Kecamatan Sungai Raya Kabupaten Pontianak, Kalimantan Barat. Jumlah petani jagung di lahan gambut di desa Limbung adalah 38 orang, maka populasi penelitian ini adalah 38 petani dan pengumpulan data dilakukan secara sensus kepada 38 petani tersebut. 
Berdasarkan tujuan penelitian yang hendak dicapai, maka jenis penelitian yang digunakan adalah penelitian deskriptif korelasional, mendeskripsikan variabel dan melihat hubungan-hubungan antarvariabel penelitian. Penelitian terdiri dari variabel bebas yaitu faktor internal petani $(X)$ dan variabel terikat yaitu kompetensi petani $(Y)$. Untuk mengetahui adanya hubungan dilakukan uji statistik, sehingga menggunakan pendekatan kuantitatif dan untuk menjelaskan substansi hasil uji statistik digunakan pendekatan kualitatif.

Pengujian hipotesis menggunakan statistik nonparametrik untuk mengukur keeratan hubungan antara faktor internal dan faktor eksternal dengan tingkat kompetensi petani. Pengujian hipotesis adalah dengan menggunakan analisis uji korelasi Rank Spearman pada $\alpha=0,05$ atau $\alpha=0,01$ (Siegel, 1992), dan untuk memudahkan pengolahan data digunakan program SPSS (Statistical Package for the Social Science) versi 13.

\section{PEMBAHASAN}

Analisis penelitian ini mendeskripsikan hubungan empat variabel bebas (karakteristik petani) dan variabel terikat (kompetensi berusaha tani). Karakteristik petani yang diidentifikasi meliputi: (1) umur, (2) pendidikan formal, (3) pengalaman berusaha tani di lahan gambut, dan (4) motivasi berusaha tani. Pada sisi umur, sejumlah besar (78,9 persen) petani jagung di lahan gambut di desa Limbung berumur antara 29 - 64 tahun; sehingga kelompok usia tersebut masih produktif untuk mengembangkan diri dan mengembangkan usaha tani. Sebagian besar (73,7 persen) petani jagung di lahan gambut berusia di atas 40 tahun.

Tampaknya sektor pertanian tidak menarik bagi tenaga kerja berusia muda. Minat tenaga kerja muda ke sektor pertanian rendah. Pemuda di desa studi lebih tertarik untuk menjadi buruh pabrik, karena mendapatkan gaji yang lebih cepat tanpa harus menunggu musim panen yang lebih lama. Rendahnya jumlah tenaga pertanian usia muda, dalam jangka panjang dapat mengkhawatirkan keberlanjutan sektor pertanian, karena kecenderungan menurunnya minat kepada sektor pertanian. Hal ini mengindikasikan perlunya penyuluhan dalam upaya meningkatkan motivasi masyarakat untuk menyenangi sektor pertanian.

Pada sisi pendidikan formal, pendidikan formal yang dimaksud dalam penelitian adalah tingkat pendidikan responden dalam mengikuti proses belajar mengajar di bangku sekolah formal. Terdapat sejumlah kecil (10,5 persen) petani yang tidak pernah duduk di bangku sekolah formal, tetapi seluruh responden dalam penelitian ini mampu membaca, menulis dan berbahasa Indonesia. Kemampuan ini merupakan modal dasar yang utama dalam memperoleh dan memahami berbagai informasi dan inovasi dalam usaha tani.

Sebagian besar (68,4 persen) petani jagung memiliki pendidikan di bawah 7 tahun; namun petani umumnya tergolong usia dewasa awal (early aduif) dan dewasa pertengahan (middle adult), yaitu: 26,3 persen berusia 29 - 40 tahun dan 52,6 persen berusia $41-64$ tahun. Pada usia dewasa awal seseorang punya kemampuan belajar yang cukup tinggi dan pada usia dewasa pertengahan, seseorang masih memungkinkan untuk diberi tambahan pendidikan sesuai dengan pekerjaan yang dilakukan (Feldman, 1996). Pendidikan nonformal dapat diberikan untuk mendukung tingkat pendidikan formal yang rendah; misalnya penyuluhan atau pelatihan sesuai kebutuhan petani.

Dari sisi pengalaman berusaha tani, penelitian ini mengukur lama (tahun) petani melakukan usaha tani di lahan gambut, baik usaha tani jagung maupun usaha tani selain jagung yang dilakukan sebelum petani berusaha tani jagung. Petani jagung di lahan gambut di desa Limbung adalah petani yang memiliki mata pencaharian utama berusaha tani jagung. Petani jagung di lahan gambut telah memiliki bekal relatif cukup lama untuk menekuni profesi sebagai petani jagung. Petani belajar bertani umumnya sejak masih kecil dari para orang tuanya. Terhitung sejak usia remaja atau telah dewasa, maka biasanya petani sudah memulai 
menggarap lahan milik orang tuanya. Orang tua membiarkan anaknya memutuskan sendiri bagaimana lahan pertanian diusahakan. Umumnya teknik-teknik usaha tani yang dikembangkan oleh para orang tuanya terdahulu tidak berbeda jauh dengan teknik-teknik yang dikembangkan oleh anaknya sehingga teknik pertanian yang banyak diterapkan adalah teknologi warisan.

Sebagian besar petani, sebelum berusaha tani jagung di lahan gambut, pernah berusaha tani komoditas selain jagung di lahan gambut. Komoditas yang ditanam dalam berusaha tani sebelumnya, diantaranya kopi, singkong, dan sayuran (tomat, kacang panjang, dan seledri). Pengalaman berusaha tani selain jagung, dapat menjadi bekal ketika berusaha tani jagung, dalam hal pengolahan lahan gambut. Teknik yang digunakan dalam pengelolaan lahan gambut ketika berușaha tani komoditas lain, juga dapat diterapkan pada waktu berusaha tani jagung di lahan gambut.

Lahan gambut punya keterbatasan dengan tingkat kemasaman lahan yang tinggi; tetapi dengan pengalaman yang cukup lama, mengantarkan petani untuk bertahan dan berusaha mengatasi kesulitan-kesulitan tersebut. Sesuai dengan pendapat Mubyarto (2002) yang menyebutkan bahwa pengalaman dan kemampuan bertani yang telah dimiliki sejak lama, sehingga telah menjadi cara hidup (way of life) yang telah memberikan keuntungan dalam hidupnya.

Terakhir, dari sisi motivasi petani, penelitian ini mengukur faktor-faktor yang mendorong petani untuk berusaha tani jagung di lahain gambut. Dorongan pemenuhan kebutuhan pangan, sandang, dan papan merupakan alasan terbesar yang mendasari petani untuk melakukan kegiatan usaha tani jagung di lahan gambut, artinya ada tujuan yang akan dicapai yang memberi dorongan lebih kepada petani untuk berusaha tani. Rata-rata motivasi petani jagung dalam melakukan aktivitas dan proses usaha tani adalah berada pada kategori sedang. Petani melakukan usaha tani jagung di lahan gambut adalah atas keinginan sendiri, dan petani merasakan keuntungan dari hasil panen yang didapatkan, sehingga para petani berpendapat usaha tani jagung di lahan gambut relatif berhasil.

Pada sisi kompetensi petani, penelitian ini mengidentifikasi tiga skala kompetensi, meliputi: (1) pengetahuan, (2) sikap, dan (3) keterampilan berusaha tani. Dari sisi pengetahuan petani, secara umum petani jagung di lahan gambut di desa Limbung memiliki pengetahuan tentang rencana usaha tani pada kategori sedang. Petani dapat menyebutkan manfaat perencanaan usaha tani dan kapan sebaiknya rencana usaha tani dilakukan, tetapi kurang tepat menyebutkan hal apa saja yang perlu diren'canakan dalam berusaha tani jagung di lahan gambut.

Pengetahuan petani tentang pengolahan lahan gambut termasuk kategori sedang. Petani tahu tentang pemakaian zat amelioran untuk mengurangi kemasaman lahan, termasuk alternatif yang bisa digunakan jika tidak tersedia kapur, tetapi petani tidak mengetahui secara detail cara pengelolaan air, untuk menjaga level air tanah gambut. Petani juga mengetahui waktu tanam yang tepat dan jarak tanam yang sesuai untuk tanaman jagung, tetapi pengetahuan tentang perlakuan benih tidak diketahui dengan baik oleh sejumlah besar $(78,95$ persen) petani. Pengetahuan tentang perlakuan benih diperlukan sebagai tindakan preventif mencegah tanaman dari penyakit.

Sebagian besar $(52,6$ persen) petani mempunyai pengetahuan tentang tindakan untuk menekan pertumbuhan gulma dan manfaat pembumbunan, tetapi petani kurang mengetahui dengan tepat dosis untuk setiap pupuk yang diberikan pada tanaman jagung. Pengetahuan tentang pemupukan menjadi sangat penting, karena pemupukan merupakan salah satu cara untuk mengatasi rendahnya hara makro dan mikro pada lahan gambut. 
Hama penyakit yang sering menyerang jagung adalah penyakit bulai. Sebagian kecil (44,7 persen) petani mengetahui nama-nama penyakit yang menyerang tanaman jagung dan gejala pada tanaman ketika tanaman mulai terserang penyakit. Sebagian besar $(73,7$ persen $)$ petani tidak dapat menyebutkan dengan tepat cara-cara pengendalian hama penyakit dalam berusaha tani tanaman jagung, termasuk pengetahuan tentang pengendalian hama penyakit secara terpadu yang tidak diketahui secara baik oleh petani.

Pengetahuan petani tentang panen termasuk kategori sedang, sejumlah besar $(89,5$ persen) petani mempunyai pengetahuan tentang ciri-ciri tanaman jagung yang siap di panen dan waktu panen yang tepat, serta sejumlah besar $(86,8$ persen) petani mengetahui cara memanen jagung yang benar. Pemanenan jagung merupakan tahapan yang sangat penting dalam teknis budidaya jagung. Kegiatan pemanenan ini akan berpengaruh terhadap kualitas dan kuantitas biji jagung yang dihasilkan, sehingga diperlukan pengetahuan yang memadai supaya kegiatan ini dapat dilakukan dengan benar.

Pengetahuan petani jagung di lahan gambut di desa Limbung tentang penanganan pascapanen termasuk kategori sedang, sejumlah besar $(84,2$ persen) petani mempunyai pengetahuan tentang manfaat pengeringan setelah jagung di panen yaitu untuk meningkatkan daya simpan, memudahkan pengolahan lebih lanjut, serta memudahkan dalam pengangkutan/ transportasi. Sebagian kecil (26,3 persen) petani dapat menyebutkan dengan baik manfaat pengupasan jagung, dan hanya sejumlah kecil ( 15,8 persen) petani yang dapat menyebutkan dengan tepat manfaat pemipilan jagung.

Pengetahuan petani tentang pemasaran termasuk kategori sedang, sebagian besar (65,8 persen) petani tahu kapan sebaiknya menjual hasil panen dan manfaat menjual jagung ke konsumen terakhir, tetapi sejumlah besar $(94,7$ persen) petani menyebutkan tidak tahu cara mempromosikan hasil panen.

Pengetahuan total petani termasuk kategori sedang. Semua bidang pengetahuan petani (delapan bidang) termasuk kategori sedang, dan tidak satu pun bidang pengetahuan yang termasuk kategori tinggi. Hal ini mengindikasikan bahwa dalam upaya meningkatkan pengetahuan petani jagung di lahan gambut di desa Limbung kegiatan penyuluhan perlu diarahkan terutama pada aspek pengetahuan yang masih rendah, méliputi: hal apa saja yang perlu direncanakan sebelum melakukan usaha tani, cara pengelolaan air untuk menjaga level air lahan gambut, perlakuan benih, dosis untuk setiap pupuk yang diberikan pada tanaman jagung, cara-cara pengendalian hama penyakit dalam berusaha tani tanaman jagung termasuk pengetahuan tentang pengendalian hama penyakit secara terpadu, manfaat pengupasan dan pemipilan jagung, serta cara mempromosikan hasil panen.

Pada sisi sikap petani, sikap petani di lahan gambut di desa Limbung tentang perencanaan usaha tani termasuk kategori sedang, sejumlah besar ( 81,6 persen) petani setuju bahwa perlu perencanaan sebelum pelaksanaan usaha tani. Sebagian kecil (45 persen) petani menyatakan setuju bahwa perencanaan harus dilaksanakan secara terperinci, meliputi: jumlah benih, pupuk, obat-obatan, waktu tanam, pemeliharaan, panen, pascapanen, dan pemasaran; dan hanya sejumlah kecil (21,2 persen) petani yang tidak tertarik untuk membuat catatan tentang perencanaan usaha tani.

Sikap petani tentang pengolahan lahan gambut, termasuk kategori sedang. Sejumlah besar (76 persen) petani setuju untuk melakukan pengapuran guna menurunkan kemasaman tanah gambut, dan setuju memberikan pupuk organik untuk menambah kesuburan lahan. Petani yang tidak setuju melakukan pengapuran, beralasan bahwa untuk mendapatkan abu hasil pembakaran lahan gambut sebagai pengganti kapur, lebih mudah daripada mesti membeli kapur. 
Sebagian kecil (34 persen) petani setuju pembuatan drainase, guna menurunkan permukaan air dalam gambut. Belajar dari petani sukses dari luar sistem sosial yang membuat drainase di lahan pertanian gambut, merupakan salah satu penyebab petani tertarik untuk membuat drainase di lahannya sendiri. Sikap petani tentang penanaman termasuk kategori rendah, hanya sejumlah kecil (7,9 persen) petani yang tertarik melakukan perlakuan benih, guna mencegah tanaman dari penyakit. Menurut Sarwono (2002), sikap terbentuk dari pengalaman, melaluj proses belajar. Pengalaman belajar responden belum memadai tentang pengetahuan perlakuan benih serta manfaatnya, sehingga mereka belum tertarik untuk melakukan hal tersebut.

Sejumlah' kecil (18 persen) petani tidak setuju untuk menentukan jarak tanam yang tepat. Kekurangan pengetahuan tentang jarak tanam yang tepat serta manfaatnya, mempengaruhi sikap petani yang tidak setuju tentang penentuan jarak tanam yảng tepat untuk tanaman jagung. Sebagian besar (73,7 persen) petani tidak setuju melakukan penyulaman, petani beralasan tidak ada persediaan benih untuk melakukan penyulaman.

Sikap petani tentang pemeliharaan termasuk kategori sedang, sebagian besar $(52,3$ persen) petani setuju untuk memberikan pupuk buatan tidak bergumpal, dan memberikan pupuk dengan dosis yang.tepat; serta sejumlah besar (76 persen) petani setuju untuk melakukan pembumbunan. Pengalaman petani selama ini dan manfaat yang dirasakan, menyebabkan sikap positif terhadap pembumbunan.

Salah satu faktor penentu peningkatan produksi jagung adalah keberhasilan mengendalikan serangan hama dan penyakit. Sebagian besar ( 68 persen) petani jagung di lahan gambut di desa Limbung setuju untuk tidak menggunakan pestisida secara berlebihan untuk mengendalikan hama dan penyakit. Pengetahuan petani yang kurang tentang pengendalian hama secara terpadu dan penggunaan tanaman perangkap untuk mengendalikan hama penyakit, sehingga sebagian besar (72 persen) petani kurang setuju untuk memanfaatkan tanaman perangkap untuk mengendalikan hama penyakit dan melakukan pengendalian hama secara terpadu.

Pengetahuan sejumlah besar $(89,5$ persen) petani tentang ciri-ciri tanaman jagung yang siap dipanen, tidak menjadikan sebagian besar petani bersikap setuju untuk selalu melakukan panen pada saat yang tepat dilihat dari ciri tanaman. Sejumlah besar (79 persen) petani tidak setuju melakukan panen pada saat yang tepat dilihat dari ciri tanaman. Desakan keperluan akan uang menyebabkan petani lebih tertarik unituk memanen jagung pada saat sudah ada permintaan pasar, walaupun belum pada saat yang tepat dilihat dari ciri tanaman.

Mendapatkan informasi dari petani lain dan pengetahuan warisan dari orang tua, semua petani setuju melakukan panen pada saat cuaca kemarau; serta pengetahuan yang salah warisan dari orang tua juga yang menyebabkan sebagian besar (65,8 persen) petani tidak setuju untuk tidak melakukan pembakaran pada saat panen. Pembakaran akan menurunkan kualitas hasil.

Sikap petani tentang penanganan pascapanen termasuk kategori sedang, sejumlah besar (92,1 persen) petani setuju mengupas jagung setelah dipanen; dan sejumlah besar ( 89,5 persen) petani setuju melakukan pengeringan, supaya jagung aman untuk disimpan, serta sebagian besar (57,9 persen) petani setuju untuk mengemas produk dengan baik, supaya harganyà lebih tinggi.

Sikap petani jagung tentang pemasaran termasuk kategori sedang, motivasi untuk mendapatkan laba yang memuaskan, menyebabkan sejumlah besar $(78,9$ persen) petani tertarik menemukan dan melakukan strategi baru dalam pemasaran. 
Keinginan untuk cepat mendapatkan uang, menjadi alasan sebagian besar (52,1 persen) petani tidak setuju menunda waktu penjualan sampai harga yang diinginkan/harga tinggi. Sebagian besar (68,4 persen) petani setuju menjual hasil panen pada konsumen terakhir untuk mendapatkan harga jual yang lebih tinggi, tetapi para petani menyebutkan tidak mengetahui jaringan pemasaran; sehingga belum bisa melakukan hal tersebut.

Sikap total petani termasuk kategori sedang, tidak ada satupun bidang sikap petani yang termasuk kategori tinggi, bahkan ada sikap petani yang rendah yaitu dalam hal penanaman. Hal ini mengindikasikan bahwa kegiatan penyuluhan kepada petani di desa Limbung kabupaten Pontianak perlu diarahkan dalam upaya mengembangkan sikap positif petani terhadap teknologi anjuran dalam berusaha tani jagung di lahan gambut. Sikap positif dapat dikembangkan dengan terlebih dahulu memberikan informasi tentang inovasi/teknologi anjuran, menunjukkan kelebihan inovasi tersebut, memperkenalkan 'motif' untuk mendorong minat petani terhadap inovasi, sebagaimana Asngari (2001) menyebutkan bahwa 'motif' dapat menjadikan klien memahami keuntungan yang diperoleh jika menerapkan suatu inovasi sehingga bersikap positif terhadap inovasi tersebut dan termotivasi untuk mengadopsinya. Materi penyuluhan untuk mengembangkan sikap positif petani sebaiknya difokuskan terutama pada aspek sikap yang masih rendah, meliputi: membuat perencanaan usaha tani secara terperinci; pembuatan drainase; melakukan perlakuan benih; melakukan penyulaman; memanfaatkan tanaman perangkap untuk mengendalikan hama penyakit; melakukan pengendalian hama secara terpadu; melakukan panen pada saat yang tepat; tidak melakukan pembakaran pada saat panen; serta menunda waktu penjualan sampai harga yang diinginkan/harga tinggi.

Sementera pada sisi keterampilan petani, keterampilan petani jagung di lahan gambut di desa Limbung dalam hal perencanaan usaha tani termasuk kategori sedang, hanya sejumlah kecil (13,2 persen) petani yang terampil membuat perencanaan tentang keuangan dan perencanaan pengembangan usaha serta juga sejumlah kecil (15,8 persen) petani yang terampil membuat perencanaan tentang pelaksanaan teknis budidaya tanaman jagung. Petani jagung mewarisi bentuk kegiatan usaha tani dari orang tua, yang tidak membuat perencanaan secara baik sebelum pelaksanaan kegiatan usaha tani dimulai.

Keterampilan petani jagung tentang pengolahan lahan gambut termasuk kategori rendah; walaupun sebagian besar (74 persen) petani terampil melakukan pencampuran amelioran pada lahan gambut, tetapi hanya sejumlah kecil (15,8 persen) petani yang bisa menentukan dosis ameliroan yang tepat. Petani jagung belajar dari petani lain, dari dalam sistem sosial maupun di luar sistem sosial, tentang pengolahan lahan gambut. Informasi yang benar tentang cara pencampuran zat amelioran yang diterima petani, sehingga proses pemberian amelioran dapat dilakukan secara benar; tetapi informasi yang kurang tepat tentang dosis amelioran yang harus dicampurkan pada lahan gambut, sehingga penentuan dosis belum tepat sebagaimana mestinya. Faktor keterbatasan modal untuk pengadaan amelioran juga menjadi alasan petani, sehingga mengurangi dosis dari yang semestinya.

Sejumlah besar ( 88 persen) petani tidak terampil membuat saluran drainase di lahan gambut, dan memang kebanyakan petani tidak membuat saluran drainase di lahan pertanian yang diusahakan. Keterampilan petani jagung dalam hal penanaman termasuk kategori sedang, walaupun hanya sejumlah kecil (5,3 persen) petani yang terampil melakukan perlakukan benih; tetapi sebagian besar (63,2 persen) petani terampil menentukan jarak tanam yang tepat untuk tanaman jagung.

Sejumlah kecil (23 persen) petani terampil melakukan penyulaman tanaman. Penyulaman seharusnya dilakukan jika ada benih yang rusak atau tidak tumbuh. Petani tidak melakukan 
penyulaman beralasan keterbatasan bibit, dan memang tidak disediakan/direncanakan bibit cadangan untuk penyulaman.

Pengetahuan petani yang kurang tentang dosis pupuk yang tepat mempengaruhi keterampilan sebagian besar $(60,5$ persen) petani, sehingga kurang terampil menentukan dosis yang tepat untuk pupuk anorganik. Sebagian besar (53 persen) petani terampil menentukan jarak dari barisan tanaman untuk pemberian pupuk dengan cara di tugal dan sejumlah besar (76 persen) petani melakukan pembumbunan dengan terampil. Keahlian ini mereka dapatkan dari warisan orang tua, dan belajar dari petani lain, dan sebagian kecil petani mendapatkan informasi dari penyuluhan yang dilakukan oleh penyuluh.

Petani jagung mempunyai tingkat keterampilan yang sedang dalam pengendalian hama dan penyakit; walaupun sejumlah besar ( 76,4 persen) petani kurang terampil melakukan pengendalian hama secara terpadu, tetapi sejumlah besar ( 82 persen) petani terampil mengidentifikasi hama dan penyakit yang menyerang tanaman jagung. Keterampilan ini didapatkan dari belajar kepada sesama petani.

Keterampilan petani jagung tentang panen, menonjol dalam hal kemampuan mengidentifikasi ciri-ciri tanaman jagung yang siap di panen dan melakukan panen secara manual, tetapi tidak sejalan dengan keterampilan dalam melakukan panen pada waktu yang tepat. Desakan ekonomi, membutuhkan uang dalam waktu cepat, terkadang menyebabkan petani melakukan panen tidak pada saat yang tepat.

Keterampilan petani dalam hal penanganan pascapanen juga termasuk kategori rendah, walaupun sebagian besar $(76,35)$ petani terampil melepaskan biji jagung dari tongkol; tetapi sejumlah besar $(81,6$ persen) petani tidak terampil melakukan sortasi dan menentukan kadar air jagung yang baik setelah penjemuran, untuk disimpan. Kendala cuaca menjadi alasan petani tidak melakukan pengeringan dengan baik, karena jika cuaca tidak memungkinkan maka proses pengeringan memerlukan waktu lama dan bisa kemungkinan akan berlangsung tidak sempurna. Pengeringan pada musim hujan memakan waktu 7 sampai 4 hari dan pada musim kemarau antara 3 sampai 7 hari.

Petani jagung di lahan gambut di desa Limbung memiliki keterampilan pemasaran yang cenderung rendah dalam hal kemampuan mencari informasi tentang harga hasil panen, menentukan waktu yang tepat untuk menjual hasil panen, dan menentukan harga jual hasil panen. Hasil panen jagung dijual kepada pedagang pengumpul yang datang ke desa responden. Harga jagung di tingkat pedagang pengumpul, pada saat penelitian, berkisar antara Rp. 1300,-- sampai dengan Rp. 1500,- per kg. Petani tidak mengetahui secara pasti dan jelas perbandingan harga hasil panen jagung di tempat lain, termasuk harga di tingkat konsumen akhir. Harga ditentukan oleh pedagang pengumpul yang datang, dan petani cenderung tidak punya pilihan lain untuk menjual dengan harga yang lebih baik.

Petani tidak memiliki kemampuan akses langsung ke dalam mekanisme pasar, petani tidak punya kemandirian menentukan harga jual jagung; secara fisik petani merasa ada pasar, tetapi petani tidak dapat langsung akses terhadap pasar karena harus melalui pedagang pengumpul atau perantara. Keberadaan pedagang pengumpul bagi petani memang dapat membantunya memasarkan hasil usaha tani ke pasar; tetapi sebagai akibatnya petani terjebak dalam mekanisme pasar, petani tunduk terhadap keputusan harga oleh pedagang pengumpul.

Keterampilan total petani jagung di lahan gambut di desa Limbung termasuk kategori sedang, tidak ada satupun bidang keterampilan petani yang termasuk kategori tinggi, bahkan beberapa bidang keterampilan petani termasuk kategori rendah yaitu dalam hal pengolahan lahan gambut, pemeliharaan dan pemupukan, penanganan pascapanen, dan pemasaran. Hal 
ini mengindikasikan bahwa kegiatan penyuluhan kepada petani di desa Limbung kabupaten Pontianak sangat perlu diarahkan dalam upaya meningkatkan keterampilan petani dalam berusaha tani jagung di lahan gambut. Pengembangan keterampilan sebaiknya dilakukan dengan memberikan contoh langsung kepada petani mengenai penerapan teknologi anjuran (seperti: demplot), sehingga petani lebih mudah memahaminya dan dapat menerapkan dalam kegiatan usaha tani. Materi penyuluhan untuk mengembangkan keterampilan petani sebaiknya difokuskan terutama pada aspek keterampilan yang masih rendah, meliputi: membuat perencanaan tentang keuangan, membuat perencanaan teknis budidaya tanaman jagung dan pengembangan usaha; menentukan dosis ameliroan yang tepat; membuat saluran drainase di lahan gambut; melakukan perlakukan benih; melakukan penyulaman tanaman; menentukan dosis yang tepat untuk pupuk anorganik; melakukan pengendalian hama secara terpadu; melakukan panen pada waktu yang tepat; melakukan sortasi dan menentukan kadar air jagung yang baijk setelah penjemuran; mencari informasi tentang harga hasil panen, menentukan waktu yang tepat untuk menjual hasil panen, dan menentukan harga jual hasil panen.

\section{KORELASI KARAKTERISTIK DENGAN KOMPETENSI PETANI}

Korelasi karakteristik dengan kompetensi petani dalam berusaha tani jagung di lahan gambut, disajikan pada Tabel.

Umur berhubungan positif sangat nyata dengan sikap petani dalam berusahatani jagung di lahan gambut. Hasil penelitian menunjukkan sejumlah besar (71 persen) petani berumur antara 45 sampai dengan 77 tahun. Kedewasaan, seiring dengan bertambah usia maka petani akan semakin banyak mengalami proses dalam usaha tani, yang menjadikan bersikap positif dalam menyikapi aspek-aspek usaha tani jagung di lahan gambut.

Pendidikan formal berhubungan positif nyata dengan pengetahuan petani dalam berusahatani jagung di lahan gambut. Hasil penelitian menunjukkan sejumlah besar $(78,9$ persen) petani mengenyam pendidikan formal selama $4-12$ tahun. Pendidikan formal yang pernah dijalani oleh petani jagung membantu pengembangan pola pikir dan daya nalar petani, sehingga dapat mengikuti perkembangan ilmu-ilmu usaha tani. Faktor pendidikan yang berhubungan positif nyata dengan tingkat pengetahuan petani, mengandung makna bahwa untuk meningkatkan pengetahuan petani, perlu memberi banyak kesempatan pengalaman belajar kepada petani, misalnya melalui pelatihan dan penyuluhan.

Tabel Korelasi Karakteristik dengan Kompetensi Petani

\begin{tabular}{|c|l|c|c|c|c|c|c|}
\hline \multirow{2}{*}{ No } & \multirow{2}{*}{ Karakteristik Petani } & \multicolumn{7}{|c|}{ Kompetensi Petani } \\
\cline { 3 - 8 } & \multicolumn{2}{|c|}{$\begin{array}{c}\text { Pengetahuan } \\
\text { Koefisien } \\
\text { korelasi }\end{array}$} & $p$ & $\begin{array}{c}\text { Koefisien } \\
\text { korelasi }\end{array}$ & $p$ & $\begin{array}{c}\text { Koefisien } \\
\text { korelasi }\end{array}$ & $p$ \\
\hline 1 & Umur & $-0,106$ & 0,402 & $\mathbf{0 , 3 9 1 ^ { * * }}$ & 0,001 & $-0,076$ & 0,548 \\
\hline 2 & Pendidikan formal & $\mathbf{0 , 3 0 2 *}$ & 0,015 & 0,139 & 0,270 & 0,211 & 0,092 \\
\hline 3 & $\begin{array}{c}\text { a. Pengalaman berusaha tani } \\
\text { jagung di lahan gambut }\end{array}$ & 0,113 & 0,353 & 0,196 & 0,104 & 0,104 & 0,392 \\
\hline & $\begin{array}{l}\text { b. Pengalaman berusaha tani } \\
\text { komoditas selain jagung } \\
\text { di lahan gambut, sebelum } \\
\text { berusaha tani jagung }\end{array}$ & $-0,030$ & 0,803 & $\mathbf{0 , 2 4 3 ^ { * }}$ & 0,043 & $-0,039$ & 0,746 \\
\hline 4 & Motivasi & $-0,041$ & 0,738 & $-0,209$ & 0,083 & 0,071 & 0,561 \\
\hline
\end{tabular}


Keterangan:

$\mathrm{n}=\mathbf{3 8}$ orang; $\mathrm{p}=$ peluang kesalahan (galat)

** Berhubungan sangat nyata pada $\alpha=0,01$

* Berhubungan nyata pada $\alpha=0,05$

Pengalaman petani dalam berusahatani komoditas selain jagung di lahan gambut, sebelum berusahatani jagung; berhubungan positif nyata dengan sikap petani dalam berusaha tani jagung di lahan gambut. Rata-rata petani mempunyai pengalaman 11,8 tahun dalam berusahatani komoditas selain jagung di lahan gambut, sebelum berusahatani jagung. Pengalaman petani dalam berusaha tani komoditas selain jagung di lahan gambut selama bertahun-tahun tersebut, menjadikan sikap positif terhadap aspek-aspek dalam usahatani jagung; karena sifat lahàn dan lahan yang sảma dengan yang pernah diolah dalam usahatani sebeluminya.

\section{KESIMPULAN}

Berdasarkan hasil dan pembahasan, maka disimpulkan setidaknya dua kesimpulan utama. Pertama, kompetensi petani jagung di lahan gambut di desa Limbung termasuk kategori sedang; kegiatan usahatani umumnya masih bersifat tradisional dan belum dilakukan secara tepat sesuai dengan teknologi anjuran. Kesimpulan kedua adalah faktor-faktor penting yang perlu diperhatikan untuk mengembangkan kompetensi petani jagung di lahan gambut meliputi: umur, pendidikan formal, dan pengalaman berusaha tani.

\section{DAFTAR PUSTAKA}

Asngari, P.S. (2001) "Peranan Agen Pembaruan/Penyuluh dalam Usaha Memberdayakan Sumberdaya Manusia Pengelola Agribisnis". Makalah Orasi Ilmiah Guru Besar Tetap IImu Sosial Ekonomi. Bogor: IPB.

[Deptan] Departemen Pertanian (2005a) Renstra Badan Litbang Pertanian 2005-2009. http:// setjen.deptan.go.id/ [19 Jan 2008].

[Deptan] Departemen Pertanian (2005b) Potenși Daerah. http://www.deptan.go.id/ [19 Jan 2008].

Feldman, R.S. (1996) Understanding Psychology. New York: McGrawHill.

Harniati (2000) Pengkajian Sistem Usaha tani Jagung di Lahan Gambut. Pontianak: Balai Pengkajian Teknologi Pertanian Kalimantan Barat.

Kristijono, A. (2003) "Pemanfaatan Lahan Gambut untukAgroindustri: Tantangan dan Peluang". Makalah Lokakarya Nasional Pertanian Lahan Gambut; Pontianak, 15-16 Desember 2003, Balai Pengkajian Teknologi Pertanian Kalimantan Barat.

Mubyarto (2002) Reformasi Agraria: Menuju Pertanian Berkelanjutan. Jurnal Ekonomi Rakyat $1: 8$.

Nursyamsi, D., I.G.M. Subiksa, A. Mulyani dan J. SriA. (2000) "Pengelolaan Lahan Marjinal untuk Meningkatkan Produksi Pertanian". Makalah Seminar Aplikasi Paket Teknologi Pertanian; Pontianak, 6-7 November 2000. Bogor: Pusat Penelitian Tanah dan Agroklimat. 
UNISIA, Vol. XXXIII No. 75 Juli 2011

Pasandaran, E dan Faisal K. (2003) Sekilas Ekonomi Jagung Indonesia: Suatu Studi di Sentra Utama Produksi Jagung. Jakarta: Deptan.

Prabowo, H.E. (2007) "Produksi Jagung 2008 Diprediksi Penuhi Kebutuhan dalam Negeri". http://www.antara.co.id/ [19 Jan 2008].

Sarwono, S.W. (2002) Psikologi Sosial: Individu dan Teori-teori Psikologi Sosial. Jakarta: Balai Pustaka.

Siegel, S. (1992) Statistik Nonparametrik: untuk Ilmu-ilmu Sosial. Jakarta: PT. Gramedia Utama.

Soekartawi (1995) Pembangunan Pertanian. Jakarta: PT. RajaGrafindo Persada. 